Announcements

\title{
Call for Papers
}

The Second International Congress in Philosophy, Phenomenology, and the Sciences of

\section{Life}

Interdisciplinary investigations pertaining to all fields of scholarship, literature, fine arts

Organiser: The World Institute for Advanced Phenomenological Research and Learning

Hosted by: The Polytechnical University of Gdansk

Place: $\quad$ Gdansk, Poland

Time: $\quad$ 5-9 June 1997

Topic: "Origins of life, individuation, evolution of types, the new critic of reason and human creative condition"

Abstracts by 1 January 1997; papers by 1 April 1997 to be sent to Professor Anna-Teresa Tymieniecka, Program Director, The World Phenomenology Institute, 348 Payson Road, Belmont, MA 02178, USA. Registration fee: US\$150.00.

\section{The Owl of Minerva}

Professor Ardis B Collins has been appointed Editor of The Owl of Minerva, the journal of The Hegel Society of America. She has also been appointed Treasurer of the Society. Address all correspondence to:

\author{
Professor Ardis B Collins \\ Department of Philosophy \\ Loyola University of Chicago \\ 6525 North Sheridan Road \\ Chicago \\ Il 60626 \\ USA \\ email: acollin@wpo.it.luc.edu
}

\section{Annual Conference of the Hegel Society of Great Britain}

The provisional dates for the annual conference are 1 and 2 September 1997, on the topic of 'Hegel and Ethics', at Pembroke College, Oxford. For further details, please contact the organiser: David Merrill, 38 Squitchey Lane, Oxford OX2 7LD. 